\title{
Skeletal muscle laminin and MDC1A: pathogenesis and treatment strategies
}

\author{
Kinga I Gawlik, Madeleine Durbeej
}

\begin{abstract}
Laminin-211 is a cell-adhesion molecule that is strongly expressed in the basement membrane of skeletal muscle. By binding to the cell surface receptors dystroglycan and integrin $\alpha 7 \beta 1$, laminin-211 is believed to protect the muscle fiber from damage under the constant stress of contractions, and to influence signal transmission events. The importance of laminin-211 in skeletal muscle is evident from merosin-deficient congenital muscular dystrophy type 1A (MDC1A), in which absence of the $\alpha 2$ chain of laminin-211 leads to skeletal muscle dysfunction. MDC1A is the commonest form of congenital muscular dystrophy in the European population. Severe hypotonia, progressive muscle weakness and wasting, joint contractures and consequent impeded motion characterize this incurable disorder, which causes great difficulty in daily life and often leads to premature death. Mice with laminin $\alpha 2$ chain deficiency have analogous phenotypes, and are reliable models for studies of disease mechanisms and potential therapeutic approaches. In this review, we introduce laminin-211 and describe its structure, expression pattern in developing and adult muscle and its receptor interactions. We will also discuss the molecular pathogenesis of MDC1A and advances toward the development of treatment.
\end{abstract}

\section{Introduction}

The basement membrane is a thin scaffold of specific extracellular protein networks associated with various cell types, including muscle fibers. This specialized framework of extracellular matrix (ECM) provides important functional cues to cells. Laminins comprise a family of glycoproteins that are major components of all basement membranes [1]. Occurrence of a laminin molecule in hydra, one of the oldest multicellular organisms, indicates that laminins existed already 600 million years ago [2]. Laminins are large (400-900 kDa) heterotrimeric molecules composed of one $\alpha$, one $\beta$ and one $\gamma$ subunit in a cruciform or T-shaped appearance. To date, five $\alpha$, three $\beta$ and three $\gamma$ chains have been characterized. They represent the products of distinct genes that evolved by duplication and recombination of ancestral $\alpha, \beta$ and $\gamma$ genes, hence they share sequence similarity. Currently, the trimers are named according to the composition of the $\alpha, \beta$ and $\gamma$ chains and more than 15 different laminin isoforms, with various arrangements of laminin subunits, have been identified [3-5]. The first laminin isoform, laminin-111, was discovered more than

\footnotetext{
* Correspondence: madeleine.durbeej-hjalt@med.lu.se

Muscle Biology Unit, Department of Experimental Medical Science, Lund University, 22184 Lund, Sweden
}

30 years ago in the Engelbreth-Holm-Swarm tumor [6]. Subsequently, laminin-211 (composed of $\alpha 2, \beta 1$ and $\gamma 1$ chains) (Figure 1) was isolated from placenta and was originally called merosin [7]. It is now well established that laminin-211 is the main laminin isoform in skeletal muscle $[8,9]$, and identification of laminin $\alpha 2$ chain mutations in a severe form of congenital muscular dystrophy (merosin-deficient congenital muscular dystrophy; MDC1A) showed the importance of laminin-211 for normal muscle function [10].

\section{Laminin $\alpha 2$ chain gene and protein}

The LAMA2 gene is located on chromosome 6q22-23 in humans and on chromosome 10 in mice [10-12]. The gene is composed of 65 exons that encode a protein with a predicted molecular mass of $390 \mathrm{kDa}$. However, it is cleaved by a furin-like convertase into a $300 \mathrm{kDa} \mathrm{N}$ terminal segment and a $80 \mathrm{kDa} C$-terminal segment, which remain non-covalently associated [13-15]. Whether this proteolytic processing has functional consequences in muscle in vivo is not known. The laminin $\alpha 2$ chain has a similar domain organization to that of the other laminin chains, with several globular and rod-like regions. Domains LN, L4a and L4b form globular structures separated by rod-like spacers of LE domains

\section{() Biomed Central}




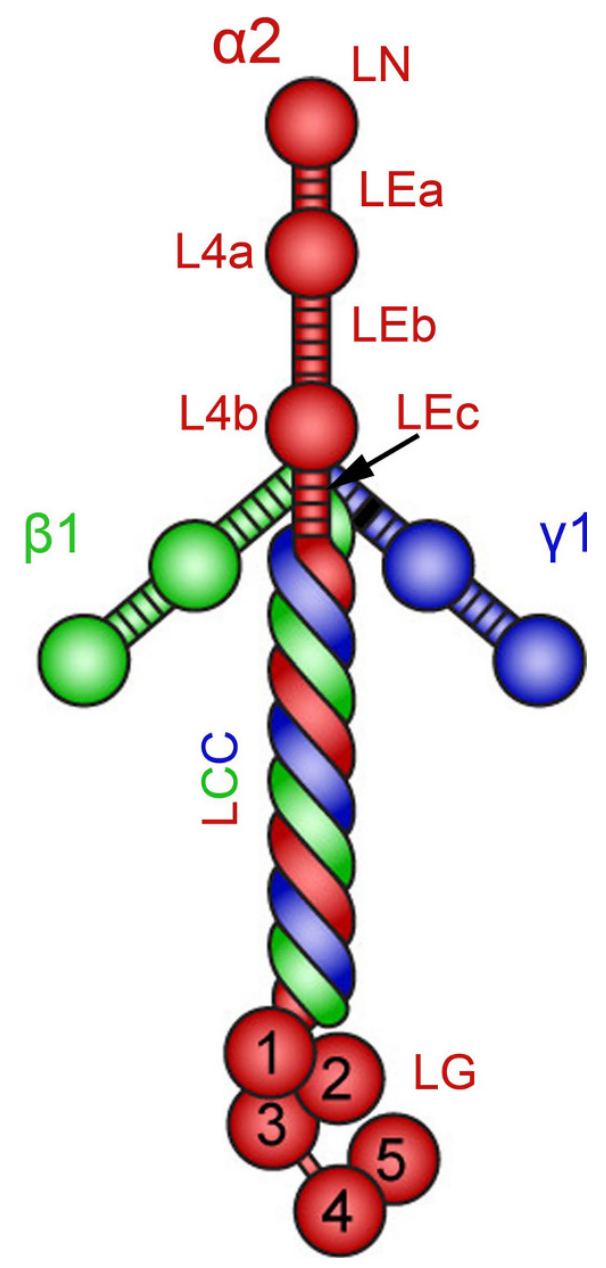

Figure 1 Scheme of laminin-211 heterotrimeric structure Laminin $\alpha 2$ chain is depicted in red, $\beta 1$ in green and $\gamma 1$ in blue. Laminin $\alpha 2$ chain consists of: the $N$ terminal globular domain $(L N)$; tandem rod domains of epidermal growth factor (LEa, LEb, LEC), separating the LN, L4a and L4b globular domains; the laminin coiled-coil (LCC) domain that tangles with the LCC domains of the $\beta 1$ and $\gamma 1$ chains; and the C-terminal laminin globular (LG) domains.

(epidermal growth factor-like repeats), followed by a coiled-coil domain, and finally, the C-terminal end is composed of five homologous laminin globular (LG) domains (LG1 to LG5) (Figure 1) [3]. Key biologic activities have been mapped to several of these domains. The LN domain is essential for laminin polymerization into supramolecular networks and consequently for incorporation into basement membranes [16], and mutations in this domain reduce the ability of polymer formation [17]. The coiled-coil domain is involved in the formation of laminin heterotrimers, and the laminin $\alpha 2$ chain can assemble with the $\beta 1, \gamma 1, \beta 2$ and $\gamma 3$ chains to form laminins 211, 221 and 213 [5]. The laminin $\alpha 2$ LG domains at the $\mathrm{C}$-terminus bind cellular receptors (dystroglycan and integrin $\alpha 7 \beta 1)[15,18]$, and such interactions are required for adhesion, basement-membrane assembly and downstream signaling events $[19,20]$.

\section{Laminin-211 and other laminins in developing muscle}

Myogenesis is a complex multistep process, but it has been found that muscle morphogenesis is strongly guided by ECM cues [21]. There is robust evidence that laminins are important for synaptogenesis [22-26], but their precise function in myogenesis is still not known. Each immature murine somite is surrounded by a laminin-111-rich basement membrane [27]. While entering the myotome during somite differentiation, muscle progenitors begin to form the myotomal basement membrane that separates the myotome and sclerotome [28], and laminin-111 seems to be fundamental for the initiation of its assembly, at least in mice [29]. After the initial myogenic events, formation of primary and secondary myotubes takes place. Basement-membrane remodeling and differential expression of laminin subunits is tightly correlated with these events. During the first fusion events in mice at embryonic day (E)11, laminin-211 and laminin-511 are the major heterotrimers of the newly formed basement membrane (the laminin $\alpha 1$ chain is still present at E11.5, but it is largely restricted to the ends of myotubes) [9]. Just before the fusion of secondary myotubes (at E14), expression of the laminin $\alpha 4$ chain increases dramatically, and it is deposited throughout the secondary myotube basement membrane by E15 [9]. In developing human muscle, the laminin $\alpha 2$ chain is present from around the seventh week of gestation, reaching maximum expression levels at week 21 $[30,31]$, and the laminin $\alpha 4$ chain is strongly expressed at week 16 [32]. Additionally, the laminin $\alpha 5$ subunit was shown to be a major laminin $\alpha$ chain during myogenesis in humans, whereas the laminin $\alpha 1$ subunit was detected only in the developing myotendinous junction (MTJ) [31,33]. It is noteworthy that the laminin composition is also modified during development of specialized muscle sites, such as the neuromuscular junction (NMJ) and the MTJ $[9,31,34]$.

Further changes om the laminin array in muscle basement membrane occur perinatally both in human and mouse as myotubes mature into myofibers. The levels of laminin $\alpha 4$ and $\alpha 5$ subunits markedly decrease at birth and are not detectable at the sarcolemma by the end of the first postnatal week $[9,32,35]$. Thus, the laminin $\alpha 2$ subunit is the only laminin $\alpha$ chain expressed in the extrasynaptic basement membrane. Interestingly, in vitro studies with myogenic cell lines found that both the laminin $\alpha 1$ and $\alpha 2$ chains possess myogenic properties, performing both shared and specific tasks in myogenesis [36,37].

Although several laminins are expressed in a distinct manner during myogenesis, none of the laminin $\alpha$ 
chains seems to be essential for this event [23,38,39]. Myogenesis occurs normally in patients and mice lacking laminin $\alpha 2$ subunit $[11,12,40-43]$, even though myofibers are smaller at birth in patients with MDC1A $[40,41]$. It is possible that laminin $\alpha 4$ and/or $\alpha 5$ could compensate for absence of the laminin $\alpha 2$ chain in developing muscle, and studies of muscles devoid of several $\alpha$ chains would be therefore be interesting. Laminins containing the $\alpha 2$ chain are instead crucial in adult muscle, and this topic will be discussed in more detail in later sections.

\section{Laminin-211 and other laminins in mature muscle}

The basement membrane surrounding the mature muscle cell (Figure 2A,B) contains laminins 211 and 221 $[8,9,44]$ (Figure 2C). To form a strongly crosslinked basement membrane, which provides significant structural support to muscle cells [45], laminins 211 and 221

\section{A}

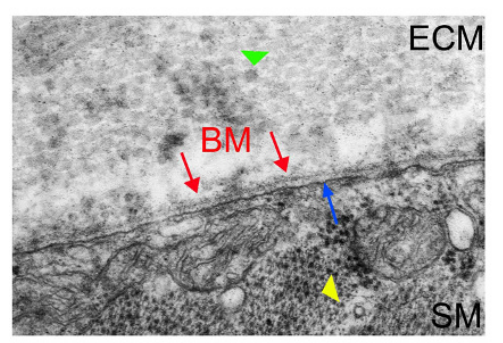

B

\section{C}

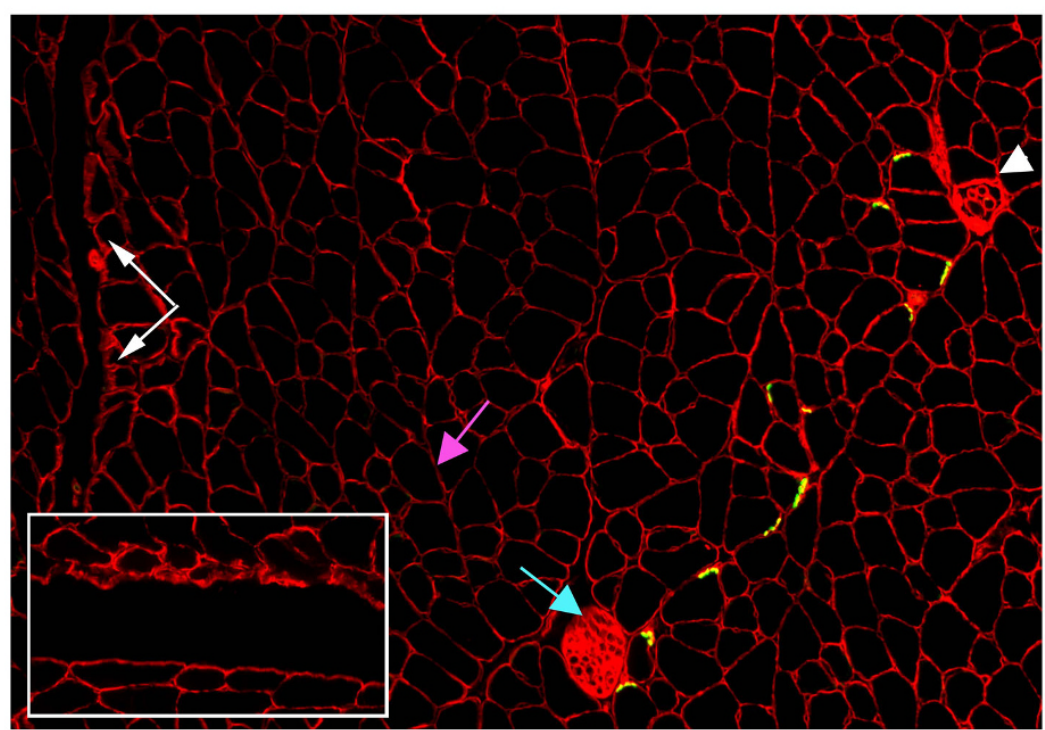

Figure 2 Basement membrane (BMs) of the neuromuscular system. (A) Electron microscopy of BMs in normal diaphragm muscle (SM, skeletal muscle). Red arrow = BM, blue arrow = sarcolemma, yellow arrowhead = sarcomere (cross-section), green arrowhead = collagen fibrils in the interstitial matrix (ECM). (B) Scheme of the motor innervation with distinct BMs. The BMs comprise a continuous layer around muscle fibers and Schwann cells of the peripheral nervous system (red layer), and there is a different composition of laminin chains and other extracellular matrix components at the neuromuscular junction (NMJ) (yellow layer). Muscle fibers and satellite cells are surrounded by an extrasynaptic BM containing mainly laminin-211. At the NMJ, laminins 221, 421 and 521 are the prominent laminin isoforms. Schwann cells at the NMJ and myelinating Schwann cells (blue = myelin) that frame the axon of the motor nerve are surrounded by a BM with slightly different laminin composition (laminins 211 and 411 as well as 221 and 421). (C) Laminin $\alpha 2$ chain expression in BMs of the neuromuscular system (immunofluorescent staining with the 4H8-2 antibody generated against the N-terminal domain of the laminin $\alpha 2$ chain). The laminin $\alpha 2$ subunit (red staining) forms the backbone of BMs that surround muscle fibers (extrasynaptic BMs) (purple arrow), underlie the NMJ (yellow) (the co-localization of laminin $\alpha 2$ chain (red staining) and acetylcholine receptors (green staining with $\alpha$-bungarotoxin) is also shown), surround Schwann cells of the intramuscular peripheral nerve (blue arrow), surround muscle spindles (white arrowhead) and underlie the myotendinous junction (MTJ) (white arrows). Inset shows a higher magnification of the MTJ. 
bind to each other and to other matrix proteins including nidogens (which in turn (connect) the laminin network to the collagen network), fibulins and agrin $[18,46]$. There are also structurally and functionally specialized basement membranes within the skeletal muscle compartment (Figure 2B,C). The sites of muscle contact with motor nerves (the NMJ) encompass three basement membranes, each with a distinct laminin expression pattern; the extrasynaptic basement membrane, the basement membrane of the synaptic cleft, and the Schwann cell basement membrane (Figure 2B). The basement membrane within the synaptic cleft contains laminins 221,421 and 521 at the sites of concentration of acetylcholine receptors (primary clefts), whereas the sites of concentration of sodium channels (folds of secondary clefts) include laminins 221 and 421 [9]. Basement membranes surrounding Schwann cells in the peripheral nervous system include mainly laminins 211, 411 [47] and probably 221 and 421 [48]. There is also a specialized junction where muscle abuts tendon (the MTJ) and laminins 211 and 221 are strongly expressed at this site [49,9] (Figure 2C).

Laminin-211 in the sarcolemmal basement membrane is extremely important for maintenance and stabilization of differentiated muscle $[37,50]$, and absence of the laminin $\alpha 2$ chain leads to muscular dystrophy in humans and mice [10-12,40-43]. Subtle NMJ defects have also been reported in laminin $\alpha 2$ chain-deficient mice [51], but it is possible that these arise from muscle abnormalities caused by the dystrophic process. The laminin $\alpha 4$ and $\beta 2$ chains, by contrast, have important roles in the NMJ. Mice devoid of the laminin $\alpha 4$ and $\beta 2$ chainshave abnormal neuromuscular (synapses) $[22,23,26]$, and laminin $\beta 2$ chain deficiency in humans (Pierson syndrome) is characterized by muscular and neurologic defects in addition to kidney failure [52].

\section{Laminin receptors in skeletal muscle}

Transmembrane receptors that interact with laminin networks, connecting them to the cytoskeleton and intracellular signaling pathways, trigger the biologic functions of laminins. The two major laminin-211/221 receptors in skeletal muscle are dystroglycan and integrin $\alpha 7 \beta 1$ (Figure 3). Dystroglycan is a highly glycosylated, ubiquitously expressed protein that consists of two subunits, $\alpha$-dystroglycan and $\beta$-dystroglycan [53]. In muscle, it forms the backbone of the multisubunit dystrophin-glycoprotein complex (DGC) linking laminin211 to the intracellular components dystrophin and actin $[54,55]$. It was recently found that a phosphorylated $O$-mannosyl glycan on $\alpha$-dystroglycan is required for laminin binding [56], which occurs through the LG domains of the laminin $\alpha 2$ chain [18]. Both laminin $\alpha 2$ LG1 to 3 and LG4 to 5 bind $\alpha$-dystroglycan strongly (whereas individual modules do not bind, except for weak interactions with the LG3 domain) [14,18]. The crystal structure has been solved for the laminin $\alpha 2$ LG4 to 5 domain, and the $\alpha$-dystroglycan binding site in the $\alpha 2$ LG4 to 5 domain has been defined [57]. Binding to $\alpha$-dystroglycan is calcium-dependent [55]. The structure of the mouse laminin $\alpha 2$ LG4 to 5 domain showed that the two calcium ions, implicated in dystroglycan binding, are located in LG4 and LG5, respectively, and the extensive basic surface region between the calcium sites is proposed to bind $\alpha$-dystroglycan [57].

Integrin $\alpha 7 \beta 1$ is the second transmembrane unit that links laminin-211 to the cytoskeleton [58-60] and binding occurs through the laminin $\alpha 2$ LG1 to 3 domain with involvement of the coiled-coil domain $[14,15]$. However, the adaptor molecules that connect integrin $\alpha 7 \beta 1$ to the cytoskeleton remain to be identified [61], although talin [62] and integrin-linked kinase [63] are likely candidates. We also recently identified a novel integrin $\alpha 7 \beta 1$ interacting protein (Cib2), whose expression in muscle is dependent on the presence of the laminin $\alpha 2$ chain [64].

The significance of the laminin receptors for normal muscle function is emphasized by the fact that mutations in DGC components and post-translational defects in dystroglycan processing and mutations in the integrin $\alpha 7$ gene causes various forms of muscular dystrophy and myopathy $[65,66]$. Hence, there is strong evidence that both receptors contribute to linking laminin-211 to the cytoskeleton and mediate the effects of laminin-211 on muscle integrity and function. It has been shown that the two systems act synergistically $[67,68]$, but separate roles have also been delineated $[69,70]$. Both dystroglycan and integrin $\alpha 7 \beta 1$ contribute to force production, but only dystroglycan is involved in anchoring the basement membrane to the sarcolemma [69]. Furthermore, different muscles may have different requirements for the laminin-dystroglycan interaction as it may not be crucial in diaphragm but important in limb muscle [70]. Nevertheless, many of the downstream events of the laminin-211-receptor interaction remain to be elucidated. Several signaling pathways may be affected, but the importance of each of those pathways in skeletal muscle is not obvious [71-76].

Finally, it should be noted that laminin-211 also binds other cell-surface receptors, although dystroglycan and integrin $\alpha 7 \beta 1$ may be considered as the major laminin211 receptors in skeletal muscle. These other receptors include the syndecans and sulfated glycolipids [18,77]. Interestingly, sulfatides have been proposed to anchor laminin-211 by binding to its LG domains to initiate basement-membrane assembly and to engage the activation of receptors (dystroglycan and $\beta 1$ integrins), at least in Schwann cells [20]. 


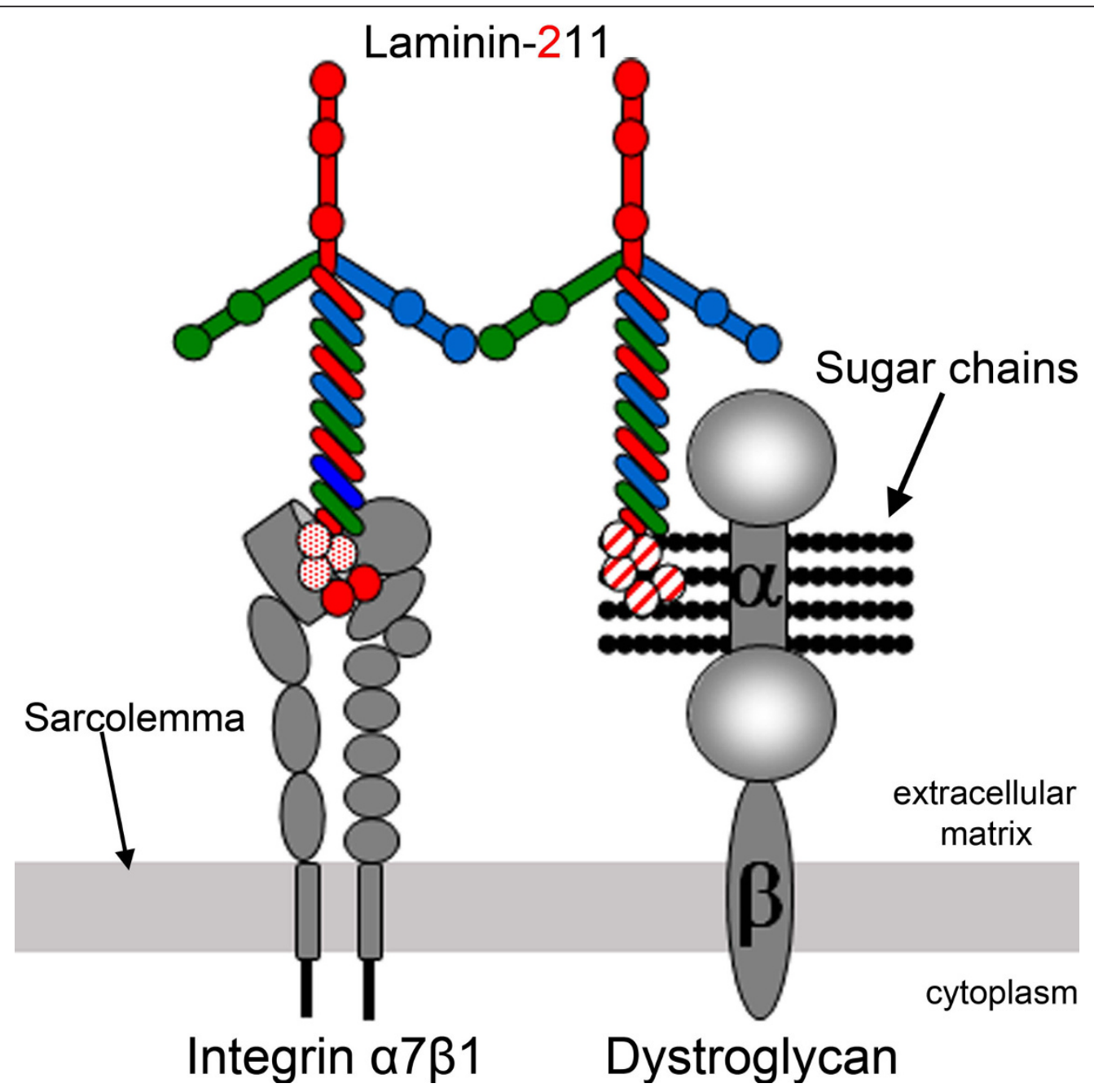

Figure 3 Laminin-211 receptors in muscle and their binding sites on the laminin $\alpha 2$ chain. Laminin $\alpha 2$ subunit binds dystroglycan and integrin $\alpha 7 \beta 1$ via the laminin globular (LG) domains. LG1 to 3 and 4 to 5 bind $\alpha$-dystroglycan, whereas only LG1 to 3 binds integrin $\alpha 7 \beta 1$. Glycosylation of $\alpha$-dystroglycan is important for laminin binding.

Congenital muscular dystrophy type $1 \mathrm{~A}$

Laminin $\alpha 2$ chain-deficient muscular dystrophy (MDC1A), showing autosomal recessive inheritance, was recognized as a particular form of congenital muscular dystrophy in 1994 when Tomé et al., found specific absence of the laminin $\alpha 2$ chain in patients [41]. Shortly after, the first causative mutations in the LAMA2 gene were identified, and a number of mutations have subsequently been reported $[10,78,79]$. It is now clear that complete laminin $\alpha 2$ chain deficiency leads to a severe phenotype, whereas partial deficiency may lead to a severe or a milder phenotype [80]. The estimated prevalence of congenital muscular dystrophy is around $7 \times 10^{-6}[81]$, and MDC1A accounts for approximately $40 \%$ of cases of congenital muscular dystrophy in Europe $[78,79]$. The clinical features of MDC1A include profound muscle hypotonia at birth and generalized muscle weakness accompanied by contractures that mostly affect the elbows, hips knees and ankles, along with scoliosis, kyphosis, increased creatine kinase levels, and delayed motor milestones (Figure 4). Patients may achieve unsupported sitting, but very few attain ambulation. Common serious complications of MDC1A include respiratory failure and feeding difficulties. Importantly, treatment with noninvasive ventilation and gastrostomy can greatly improve health. However, respiratory-tract infection is the commonest cause of death, which may occur in the first decade of life or anytime subsequently $[78,79]$. As the laminin $\alpha 2$ chain is also expressed in the central nervous system (CNS), peripheral nervous system and heart [8], these tissues are also affected to various degrees in MDC1A. Most patients (after 1 year of age) display white-matter 


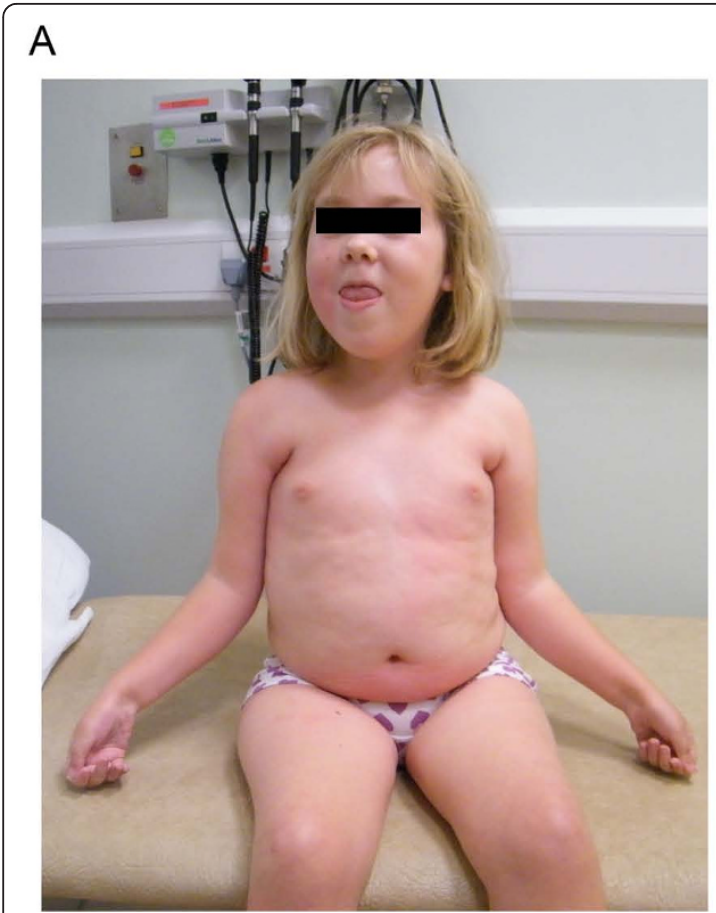

B

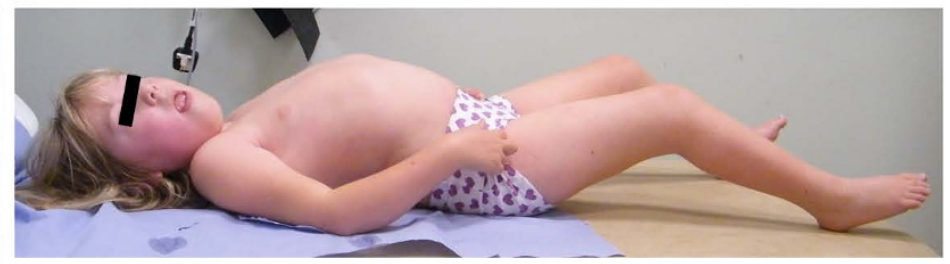

C

Figure 4 Clinical features of a patient with merosin-deficient congenital muscular dystrophy (MDC1A) with complete laminin $\alpha 2$ chain deficiency. (A) Facial weakness with an open mouth and reduced facial expression. Patient has developed bilateral elbow-flexion contractures, a fairly common sign in patients with MDC1A. (B) Bilateral knee-flexion contractures and lumbar hyperlordosis. (C) Truncal weakness and neckflexion weakness (lack of head control) when the patient is pulled up from a lying position. Informed consent was obtained from the patient's parents for publication of the photographs.

abnormalities, which are readily detected with magnetic resonance imaging, but these changes do not seem to be associated with any particular functional impairment. Structural brain changes have been reported in some patients, and epilepsy may be present. Moreover, patients have decreased peripheral nerve conduction velocity because of myelination defects. Severe heart failure is rare in MDC1A, but left ventricular dysfunction has been reported in about $30 \%$ of patients $[78,79,82]$. No treatment is currently available for this devastating disease.

\section{Mouse models for laminin $\alpha 2$ chain deficiency}

A number of mouse models for laminin $\alpha 2$ chain deficiency exist, and in general they adequately model human disease. In addition, they confirm the relationship between laminin $\alpha 2$ chain expression and severity of disease [83] (Table 1 and references therein). The $d y /$ $d y$ mouse expresses reduced levels of an apparently normal laminin $\alpha 2$ chain, but the causative mutation remains to be identified. The $d y / d y$ mouse displays moderate muscular dystrophy, peripheral neuropathy, heart fibrosis and defects in CNS myelination $[11,12,84]$. The $d y^{2 J} / d y^{2 J}$ mouse harbors a mutation in the $\mathrm{N}$ terminal (LN) domain, which leads to abnormal splicing and slightly reduced expression of a laminin $\alpha 2$ chain lacking this domain. These mice display a relatively mild muscular dystrophy and peripheral neuropathy $[85,86]$. Two further mouse models have been generated by homologous recombination: the $d y^{W} / d y^{W}$ mouse expresses small amounts of a truncated $\alpha 2$ chain lacking the LN domain whereas the $d y^{3 K} / d y^{3 K}$ mouse (Figure 5) is completely deficient in the laminin $\alpha 2$ chain. Both $d y^{W} / d y^{W}$ and $d y^{3 K} / d y^{3 K}$ mice develop severe muscular dystrophy and die within a few weeks of age. They also exhibit pronounced hind-leg lameness $[42,43,83]$. Nevertheless, it seems that the phenotype of the $d y^{3 K} / d y^{3 K}$ mouse is more severe than that of the $d y^{W} / d y^{W}$ mouse, and it could be that the residual laminin $\alpha 2$ chain expression in $d y^{W} / d y^{W}$ muscle is beneficial. The most recently described mouse model is the $d y^{n m j 417} / d y^{n m j 417}$ mouse, in which a single point mutation in the LN domain leads to normal levels of a mutated laminin $\alpha 2$ chain and mild muscular dystrophy [87].

Although it can be debated whether mice are reliable as preclinical models for human disease, analyses of the various laminin $\alpha 2$ chain-deficient mouse models have led to a significant improvement in our understanding of development of MDC1A. More importantly, they have been valuable tools for the development of novel therapeutic approaches for laminin $\alpha 2$ chain deficiency. 
Table 1 Mouse models for laminin $\alpha 2$ chain deficiency

\begin{tabular}{|c|c|c|c|}
\hline $\begin{array}{l}\text { Mouse } \\
\text { model }\end{array}$ & Mutation/protein product & Phenotype & Ref \\
\hline$d y / d y$ & $\begin{array}{l}\text { Unknown spontaneous mutation/reduced } \\
\text { expression of seemingly normal } \alpha 2 \text { chain }\end{array}$ & $\begin{array}{l}\text { Lethal within } 6 \text { months of age. Moderate muscular dystrophy; } \\
\text { peripheral neuropathy; defective central nervous system } \\
\text { myelination; hearing loss; aberrant thymocyte development }\end{array}$ & {$[11,12,84,121,122]$} \\
\hline$d y^{2 \jmath} / d y^{2 \jmath}$ & $\begin{array}{l}\text { Spontaneous mutation in } L N \text { domain }{ }^{a} / \text { lightly } \\
\text { reduced expression of truncated } \alpha 2 \text { chain devoid } \\
\text { of } L N \text { domain }\end{array}$ & Normal lifespan. Mild muscular dystrophy; peripheral neuropathy & {$[85,86]$} \\
\hline$d y^{W} / d y^{W}$ & $\begin{array}{l}\text { Knock- out/severely reduced expression of } \\
\text { truncated } \alpha 2 \text { chain devoid of } L N \text { domain }\end{array}$ & $\begin{array}{l}\text { Lethal at } 10 \text { to } 15 \text { weeks of age. Severe muscular dystrophy; } \\
\text { peripheral neuropathy }\end{array}$ & {$[43,83]$} \\
\hline$d y^{3 K} / d y^{3 K}$ & Knock-out/complete deficiency & $\begin{array}{l}\text { Lethal at } 4 \text { weeks of age. Severe muscular dystrophy; peripheral } \\
\text { neuropathy; impaired spermatogenesis; defective odontoblast } \\
\text { differentiation }\end{array}$ & {$[42,123-125]$} \\
\hline $\begin{array}{l}d y^{n m j 417} / \\
d y^{n m 4417}\end{array}$ & $\begin{array}{l}\text { N-ethyl-N-nitrosourea-induced point mutation in } \\
\text { LN domain/normal levels }\end{array}$ & Normal lifespan. Mild muscular dystrophy; peripheral neuropathy & {$[87]$} \\
\hline $\begin{array}{l}d y^{\text {Pas }} / d y^{\text {Pas }} \\
\text { (now } \\
\text { extinct) }\end{array}$ & $\begin{array}{l}\text { Spontaneous retrotransposal insertion/severe } \\
\text { deficiency }\end{array}$ & $\begin{array}{l}\text { Died at } 13 \text { weeks of age. Severe muscular dystrophy; peripheral } \\
\text { neuropathy }\end{array}$ & [126] \\
\hline
\end{tabular}

${ }^{\mathrm{L} N}=$ laminin $\mathrm{N}$-terminal domain.

\section{Pathogenesis of MDC1A muscle}

Although the primary defect in MDC1A is known to be loss of the laminin $\alpha 2$ chain, the secondary molecular mechanisms ultimately leading to muscle degeneration have yet to be determined. Absence of laminin $\alpha 2$ from skeletal muscle gives rise to a marked dystrophic pattern with muscle fiber-size variation (with atrophy predominance), central nucleation and extensive fibrosis (Figure 6) [79]. Further features typical of MDC1A include disrupted basement membranes [11] and increased apoptosis $[88,89]$. It has been suggested that the laminin $\alpha 2$ chain confers a structural link (by binding to dystroglycan) from the ECM to the cytoskeleton, and that such linkage stabilizes the muscle-cell membrane and protects it from contraction-induced damage $[90,91]$. However, this hypothesis was challenged by Hall et al. [92]. Using a zebrafish laminin $\alpha 2$-chain mutant, they suggested that damage to the muscle fiber occurs by mechanically induced fiber detachment in the absence of sarcolemma rupture, and that detached fibers undergo apoptosis. Nevertheless, cell membranes are ruptured to some extent in animals with complete laminin $\alpha 2$ chain deficiency [70] and it has been proposed that laminin $\alpha 2$ chain binding to $\alpha$-dystroglycan strengthens the sarcolemmal integrity [69]. The downstream signaling events leading to apoptosis remain to be deciphered, but recent data suggest that it includes glyceraldehyde-3-phosphate dehydrogenase (GAPDH)Siah1-CBP/p300-p53 signaling [93]. However, there are relatively few apoptotic fibers in laminin $\alpha 2$ chaindeficient muscles $[89,93]$, hence there must be other mechanisms underlying the muscle wasting seen in MDC1A. Both the ubiquitin-proteasome system and the autophagy-lysosome pathway play key roles in protein degradation in skeletal muscle cells [94]. Interestingly, we recently found that increased proteasomal degradation is a feature of $d y^{3 K} / d y^{3 K}$ muscle [95], and preliminary unpublished data indicate that there might also be excessive autophagy in $d y^{3 K} / d y^{3 K}$ muscle. Defects in both of these degradative systems have also been found in other muscular dystrophies. For example, Duchenne muscular dystrophy pathogenesis may involve proteasomal degradation of dystrophin and the DGC [96], and autophagy is impaired (but not increased as in MDC1A) in collagen VI-deficient muscular dystrophy [97].

At the molecular level, absence of the laminin $\alpha 2$ chain affects the expression and localization of several other laminin chains and cell-surface receptors. In particular, expression of the laminin $\beta 2$ chain is severely reduced from the sarcolemmal basement membranes in laminin $\alpha 2$ chain-deficient muscle [44]. Conversely, laminin $\alpha 4$ (and $\alpha 5$ chain to some extent) is increased at this site $[9,98]$. However, it does not seem to compensate for the absence of the laminin $\alpha 2$ chain, presumably because the laminin $\alpha 4$ chain cannot bind $\alpha$-dystroglycan [99], or possibly because that the laminin $\alpha 4$ chain is not upregulated in sufficient amounts. In extraocular muscles, which have a number of differences from other skeletal muscles, the laminin $\alpha 4$ chain is strongly expressed in the basement membrane adjoining the sarcolemma, and its expression is further enhanced in the extraocular muscle of $d y^{3 K} / d y^{3 K}$ animals. Interestingly, laminin $\alpha 2$ chain-deficient extraocular muscles are spared from dystrophic changes, and it has been hypothesized that binding of the laminin $\alpha 4$ chain to integrin $\alpha 7 \beta 1$ may protect the extraocular muscles from damage [100,101].

Changes in the expression of laminin-211 receptors might also contribute to the pathology of MDC1A. A dramatic decrease of integrin $\alpha 7$ subunit in muscle from 


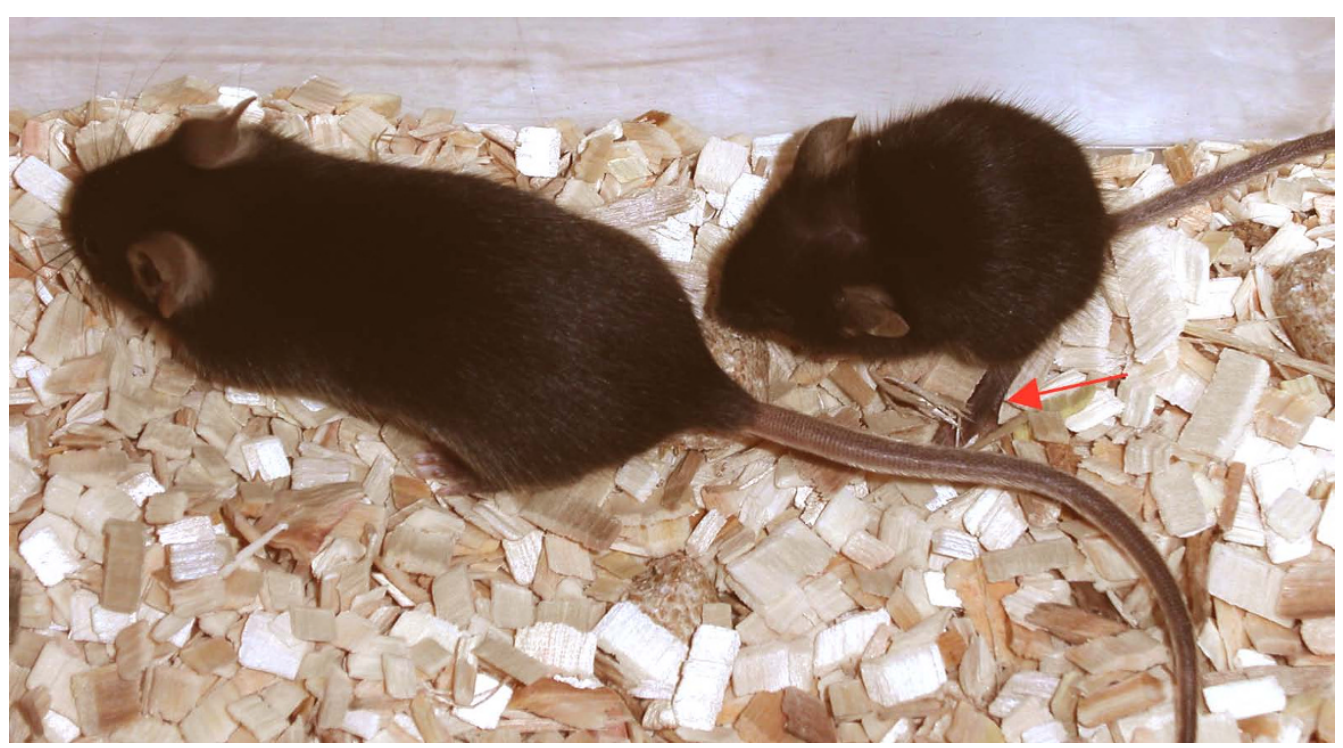

Figure $5 \mathrm{~A} d y^{3 K} / d y^{3 K}$ laminin $\alpha 2$ chain-deficient mouse with a littermate (both 5 weeks old). Laminin $\alpha 2$ chain knockout mice have severe muscle wasting and growth retardation, resulting in dramatically decreased weight. Hind-limb paralysis (depicted with arrow), a result of peripheral neuropathy, is often seen before death.

laminin $\alpha 2$ chain-deficient patients and mice [60,102,103], and a striking impairment of its deposition at the sarcolemma [104], has been noted, suggesting that integrin $\alpha 7 \beta 1$ signaling is abolished. By contrast, expression of $\beta$-dystroglycan at the sarcolemma, is upregulated in laminin $\alpha 2$ chain-deficient mouse muscle [104,105]. However, conflicting data have been reported on $\alpha$-dystroglycan expression, with its production either not found to be significantly affected by laminin $\alpha 2$ chain deficiency $[60,103]$ or shown to be moderately increased [104]. Moll et al. and Jimenez-Mallebrera et al. reported severe reduction of $\alpha$-dystroglycan core protein $[105,106]$. The precise physiological outcomes of receptor alterations remain largely unknown, but altogether they point towards a central position of laminin-211 in regulating the expression of $\alpha 7 \beta 1$ and dystroglycan.

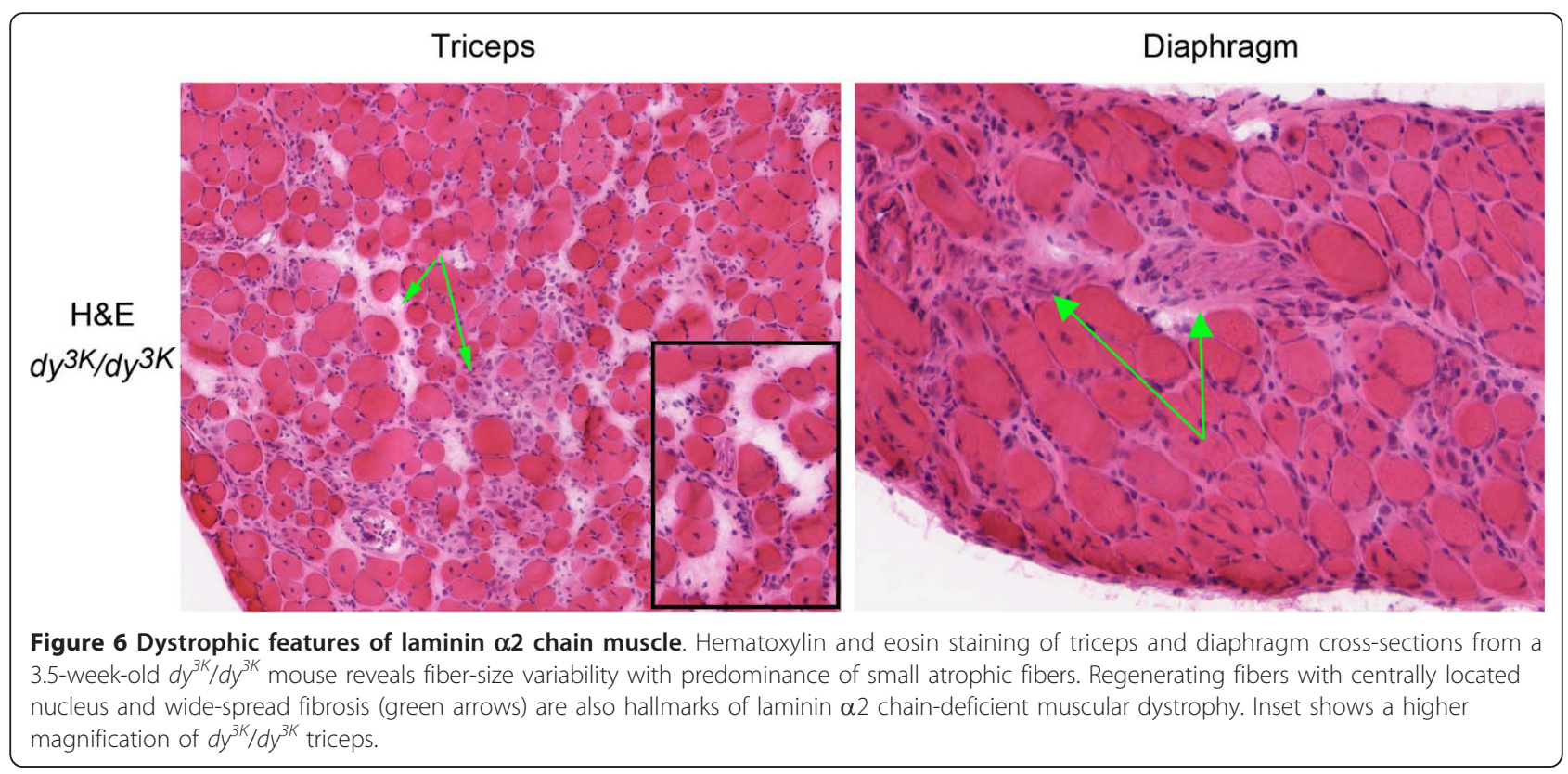




\section{Amelioration of disease in mice}

Several strategies to combat disease in MDC1A mouse models have been explored during the past decade. Because the basement membrane is affected in MDC1A, many of these approaches have targeted the expression of ECM proteins. Transgenic expression of the laminin $\alpha 1$ and $\alpha 2$ chains, mini-agrin, and cytotoxic T cell GalNac transferase have been found to compensate for laminin $\alpha 2$ chain deficiency in mice [43,105,107-109]. $D y^{W} / d y^{W}$ mice bred to overexpress linker molecules (for example, mini-agrin, full-length agrin, agrin-perlecan fusion protein) between the laminin $\alpha 4$ chain and dystroglycan have a prolonged lifespan and significantly improved muscle tissue. Importantly, it was also found that mini-agrin can slow down the progression of disease at every stage $[105,107,110]$. The effects of laminin $\alpha 1$ chain overexpression in the neuromuscular system have also been extensively studied, and it has been shown that $d y^{3 K} / d y^{3 K}$ mice overexpressing the laminin $\alpha 1$ chain have a near-normal lifespan and display considerably improved muscle, heart and nerve morphology and function $[48,108,111]$ (Figure 7; see Additional file 1). The reduction in muscle fibrosis was particularly marked in these animals. Because transgenic expression of laminin $\alpha 1$ chain reconstituted integrin $\alpha 7$ at the sarcolemma [104], we reasoned that the laminin $\alpha 1$ chain mediated reduction of laminin $\alpha 2$ chain deficient muscular dystrophy mainly involves integrin $\alpha 7 \beta 1$ (which also binds laminin $\alpha 1$ chain with high affinity [112]). Consistent with this notion, a laminin $\alpha 1$ chain devoid of the dystroglycan binding site but retaining the

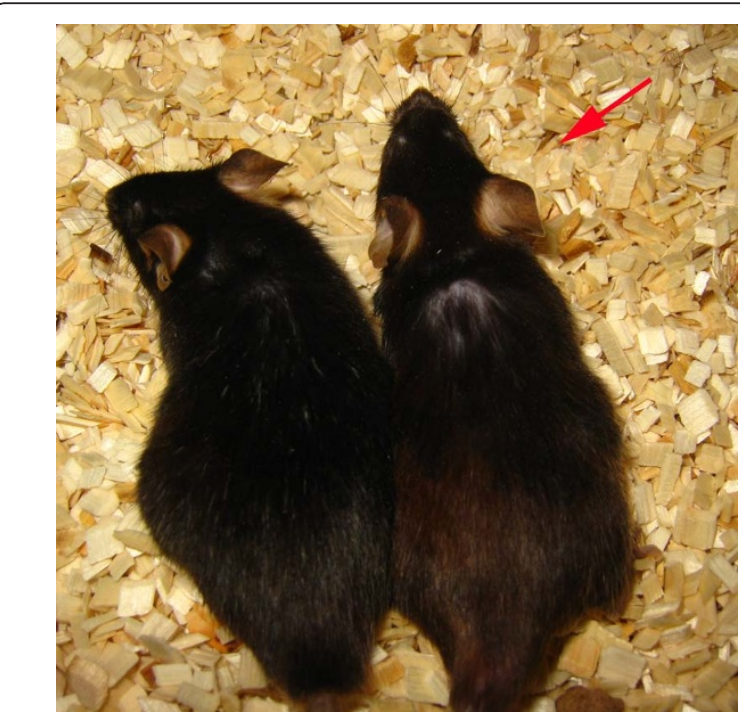

Figure 7 A 2-year-old laminin $\alpha 2$ chain-deficient mouse $\left(d y^{3 K} /\right.$ $d y^{3 K}$ ) overexpressing laminin $\alpha 1$ chain, with a wild-type littermate. Laminin $\alpha 1$ chain overexpression resulted in a remarkable improvement of overall health and prevention of muscular dystrophy that persisted throughout life. integrin $\alpha 7 \beta 1$ binding domain significantly increased the lifespan of $d y^{3 K} / d y^{3 K}$ mice and partially rescued dystrophic muscles, in particular the diaphragm [70]. However, subtle muscle defects (that is, residual degeneration) were seen in old animals overexpressing fulllength laminin $\alpha 1$ chain [111]. Hence, it is possible that laminin $\alpha 1$ chain interactions with integrin $\alpha 7 \beta 1$ and dystroglycan might trigger different signaling cascades to those triggered by the laminin $\alpha 2$ chain.

Despite significant therapeutic benefits in mice, it is important to realize that these transgenic approaches are not clinically feasible. Therefore, adenoassociated virus-mediated gene transfer of mini-agrin was tested in $d y^{W} / d y^{W}$ and $d y / d y$ mice. Notably, systemic gene delivery of mini-agrin improved the overall phenotype and muscle function in treated animals [113].

Several approaches aimed at assuaging the secondary defects in MDC1A, instead of targeting the primary deficiency, have also been undertaken. As increased apoptosis had been suggested to contribute to the pathology of MDC1A, Miller et al. caused either inactivation of the proapoptotic protein Bax or overexpression of the antiapoptotic protein Bcl-2 in $d y^{W} / d y^{W}$ animals $[114,115]$; both of these genetic interventions improved the health of the animals. Overexpression of Bcl-2 had no major effect in dystrophin-deficient mice, indicating that Bcl-2-mediated apoptosis is a more significant contributor to the pathogenesis of MDC1A than that of Duchenne muscular dystrophy [115]. The same group also recently explored the use of anti-apoptotic pharmacologic treatment. Interestingly, treatment with minocycline or doxycycline increased the lifespan of $d y^{W} / d y^{W}$ animals and lessened muscle pathology [116]. Similarly, treatment with omigapil, which inhibits GAPDH-Siah1mediated apoptosis, ameliorated the pathological features in $d y^{W} / d y^{W}$ animals [93]. Recently, it was also established that mitochondria isolated from $d y^{W} / d y^{W}$ muscle are swollen. This is a typical feature of abnormal opening of the permeability transition pore caused by a strong increase in intracellular calcium (which may be detrimental for the muscle cell). Persistent opening may cause mitochondrial rupture and subsequent cell death. Laminin $\alpha 2$ chain-deficient $d y^{W} / d y^{W}$ mice devoid of cyclophilin-D, which is a regulatory protein of the permeability transition pore, displayed reduced muscular dystrophy pathology [117]. Additionally, because enhanced proteasomal degradation is a feature of laminin $\alpha 2$ chain-deficient muscle [95], we hypothesized that inhibition of the proteasome would lessen the myopathology, and indeed, treatment with the proteasome inhibitor MG-132 significantly improved the lifespan and muscle morphology of $d y^{3 K} / d y^{3 K}$ mice [95].

Finally, cell therapy has been evaluated in mouse models of MDC1A. Myoblast and CD90-positive cell 
transplantation led to laminin $\alpha 2$ chain expression in $d y / d y$ and $d y^{3 K} / d y^{3 K}$ mice, respectively, but no further improvement in the animals, was reported $[118,119]$. However, bone-marrow transplantation improved life span, growth rate, muscle strength and importantly, respiratory function of $d y / d y$ animals [120].

Altogether, considering that laminin $\alpha 2$ chain deficiency seems to affect different cellular events, combinatorial treatment strategies (for example, apoptosis and proteasome inhibitors together with replacement therapy) may be relevant for MDC1A. Moreover, bearing in mind that MDC1A is associated with peripheral neuropathy, therapies that also alleviate the neurologic dysfunction should be favored. Previous studies found that motor nerve pathology could not be prevented by muscle-specific expression of laminin $\alpha 2$ chain [43] and mini-agrin [105], whereas ubiquitous expression of the laminin $\alpha 1$ chain significantly reduced peripheral neuropathy [48]. In addition, inactivation of Bax s [114] and treatment with doxycycline [116] were reported to be beneficial for the condition of motor neuron.

\section{Conclusion}

A great deal is known about the structure and function of laminin-211, and advances concerning the development of future therapies have been made for murine laminin $\alpha 2$ chain-deficient muscular dystrophy. Absence of the laminin $\alpha 2$ chain does not only affect skeletal muscle but also several non-muscle tissues. Analysis of these organs has been hampered by the relatively early death of the animals. It would therefore be informative to analyze the non-muscle organs in animals that have been rescued from the muscle defects or to generate mice with a tissue-specific disruption of the laminin $\alpha 2$ chain. Furthermore, the targeted genetic elimination of individual laminin domains (in particular the LG domains) would be valuable to understand their role in vivo. Finally, elucidation of laminin $\alpha 2$ chain-induced signal transduction pathways is an important task. Such studies would be helpful to further clarify the details of laminin $\alpha 2$ chain function to design future treatment for MDC1A.

\section{Additional material}

Additional file 1: Supplemental video 1. A 2-year-old laminin $\alpha 2$ chain-deficient mouse $\left(d y^{3 K} / d y^{3 K}\right)$ overexpressing laminin $\alpha 1$ chain together with a wild-type littermate. The rescue mouse is denoted with a blue pointer at the beginning of the $\mathrm{f}$. Both mice were placed in a new cage. The $d y^{3 K} \mathrm{LM} \alpha 1$ mouse is as active as wild-type littermate; it explores the cage and often stands up on its hind limbs.

\section{Abbreviations}

CBP: CAMP response element binding protein (CREB) binding protein.

\section{Acknowledgements}

This work was supported by Muscular Dystrophy Association. We are very grateful to Professor Volker Straub and the patient and family for their permission to use the photographs.

\section{Authors' contributions}

KIG And MD wrote the paper.

\section{Authors' information}

KIG is a post-doctoral student at the Department of Experimental Medical Science, University of Lund, with a PhD in cell and molecular biology, specializing in preclinical studies of laminins and muscle disease. MD is a professor in muscle biology at the Department of Experimental Medical Science, University of Lund, with a PhD in animal physiology, specializing in preclinical studies of laminins and muscle disease.

\section{Competing interests}

The authors declare that they have no competing interests.

Received: 6 December 2010 Accepted: 1 March 2011

Published: 1 March 2011

\section{References}

1. Miner $\mathrm{JH}$, Yurchenco PD: Laminin functions in tissue morphogenesis. Annu Rev Cell Dev Biol 2004, 20:255-284.

2. Sarass MP Jr, Yan L, Grens A, Zhang X, Agbas A, Huff JK, St John PL, Abrahamson DR: Cloning and biological function of laminin in Hydra vulgaris. Dev Biol 1994, 164:312-324.

3. Aumailley M, Bruckner-Tuderman L, Carter WG, Deutzmann R, Edgar D, Ekblom P, Engel J, Engvall E, Hohenester E, Jones JC, Kleinman HK, Marinkovich MP, Martin GR, Mayer U, Meneguzzi G, Miner JH, Miyazaki K, Patarroyo M, Paulsson M, Quaranta V, Sanes JR, Sasaki T, Sekiguchi K, Sorokin LM, Talts JF, Tryggvason K, Uitto J, Virtanen I, von der Mark K, Wewer UM, Yamada Y, Yurchenco PD: A simplified laminin nomenclature. Matrix Biol 2005, 24:326-332.

4. Tzu J, Marinkovich MP: Bridging structure with function: structural, regulatory, and developmental roles of laminins. Int I Biochem Cell Biol 2008, 40:199-214.

5. McDonald PR, Lustig A, Steinmetz MO, Kammerer RA: Laminin chain assembly is regulated by specific coiled-coil interactions. J Struct Biol 2010, 170:398-405

6. Timpl R, Rohde H, Robey PG, Rennard SI, Foidart JM, Martin GM: Laminin- a glycoprotein from basement membranes. J Biol Chem 1979, 254:9933-9937.

7. Ehrig K, Leivo I, Argraves WS, Ruoslahti E, Engvall E: Merosin, a tissuespecific basement membrane protein, is a laminin-like protein. Proc Natl Acad Sci USA 1991, 87:3264-3268.

8. Leivo I, Engvall E: Merosin, a protein specific for basement membranes of Schwann cells, striated muscle, and trophoblast, is expressed late in nerve and muscle development. Proc Natl Acad Sci USA 1988, 85:1544-1588.

9. Patton BL, Miner JH, Chiu AY, Sanes JR: Distribution and functions of laminins in the neuromuscular system of developing, adult, and mutant mice. J Cell Biol 1997, 139:1507-1521.

10. Helbling-Leclerc A, Zhang X, Topaloglu H, Cruaud C, Tesson F, Weissenbach J, Tomé FMS, Schwartz K, Fardeau M, Tryggvason K, Guicheney P: Mutations in the laminin a2 chain gene (LAMA2) cause merosin-deficient muscular dystrophy. Nat Genet 1995, 11:216-218

11. Xu H, Christmas P, Wu XR, Wewer UM, Engvall E: Defective muscle basement membrane and lack of M-laminin in the dystrophic dy/dy mouse. Proc Natl Acad Sci USA 1994, 91:5572-5576.

12. Sunada Y, Bernier SM, Utani A, Yamada Y, Campbell KP: Deficiency of merosin in dystrophic dy mice and genetic linkage of laminin $M$ chain to dy locus. J Biol Chem 1994, 269:13279-13732.

13. Paulsson M, Saladin K, Engvall E: Structure of laminin variants: The $300-$ $\mathrm{kDa}$ chains of murine and bovine heart laminin are related to the human placenta merosin heavy chain and replace the a chain in some laminin variants. J Biol Chem 1991, 266:17545-17551.

14. Talts JF, Mann K, Yamada Y, Timpl R: Structural analysis and proteolytic processing of recombinant $\mathrm{G}$ domain of mouse laminin a2 chain. FEBS Lett 1998, 426:71-76. 
15. Smirnov SP, McDearmon EL, Li S, Ervasti JM, Tryggvason K, Yurchenco PD: Contributions of the LG modules and furin processing to laminin-2 functions. J Biol Chem 2002, 277:18928-18937.

16. Yurchenco PD, O'Rear JJ: Basement membrane assembly. Methods Enzymol 1994, 245:489-518.

17. Colognato $H$, Yurchenco PD: The laminin a2 expressed by dystrophic dy (2J) mice is defective in its ability to form polymers. Curr Biol 1999, 9:1327-1330

18. Talts JF, Andac Z, Gohring W, Brancaccio A, Timpl R: Binding of the G domains of laminin $\alpha 1$ and $a 2$ chains and perlecan to heparin, sulfatides, a-dystroglycan and several extracellular matrix proteins. EMBO J 1999, 18:863-870.

19. Talts JF, Timpl R: Mutation of a basic sequence in the laminin a2LG3 module leads to a lack of proteolytic processing and has different effects on $\beta 1$ integrin-mediated cell adhesion and a-dystroglycan binding. FEBS Lett 1999, 458:319-23.

20. Li S, Liquari P, McKee KK, Harrison D, Patel R, Lee S, Yurchenco PD: Laminin-sulfatide binding initiates basement membrane assembly and enables receptor signaling in Schwann cells and fibroblasts. $J$ Cell Biol 2005, 169:179-189.

21. Sanes JR: The extracellular matrix. In Myology. Volume 1. Edited by: Engel A, Franzini-Armstrong C. New York: McGraw-Hill; 2004:471-488.

22. Noakes PG, Gautam M, Mudd J, Sanes JR, Merlie JP: Aberrant differentiation of neuromuscular junctions in mice lacking s-laminin/ laminin $\beta 2$. Nature 1995, 374:258-262.

23. Patton BL, Cunningham JM, Thyboll J, Kortesmaa J, Westerblad H, Edstrom L, Tryggvason K, Sanes JR: Properly formed but improperly localized synaptic specializations in the absence of laminin a4. Nat Neurosci 2001, 4:597-604.

24. Nishimune H, Sanes JR, Carlson SS: A synaptic laminin-calcium channel interaction organizes active zones in motor nerve terminals. Nature 2004, 432:580-587.

25. Nishimune $H$, Valdez $G$, Jarad G, Moulson $C L$, Müller U, Miner JH, Sanes JR: Laminins promote postsynaptic maturation by an autocrine mechanism at the neuromuscular junction. J Cell Biol 2008, 182:1201-1215.

26. Miner JH, Go G, Cunningham J, Patton BL, Jarad G: Transgenic isolation of skeletal muscle and kidney defects in laminin $\beta 2$ mutant mice: implications for Pierson syndrome. Development 2006, 133:967-975.

27. Tiger CF, Gullberg D: Absence of laminin a1 chain in the skeletal muscle of dystrophic dy/dy mice. Muscle Nerve 1997, 12:1515-1524.

28. Tosney KW, Dehnbostel DB, Erickson CA: Neural crest prefer the myotome's basal lamina over the sclerotome as a substratum. Dev Biol 1994, 163:389-406.

29. Anderson C, Thorsteinsdottir S, Borycki AG: Sonic hedgehog-dependent synthesis of laminin a1 controls basement membrane assembly in the myotome. Development 2009, 136:3495-3504.

30. Sewry CA, Chevallay M, Tomé FM: Expression of laminin subunits in human fetal skeletal muscle. Histochem J 1995, 27:497-504

31. Pedrosa-Domellöf F, Tiger CF, Virtanen I, Thornell LE, Gullberg D: Laminin chains in developing and adult human myotendinous junctions. $J$ Histochem Cytochem 2000, 48:201-210.

32. Petäjäniemi N, Korhonen M, Kortesmaa J, Tryggvason K, Sekiguchi K, Fujiwara H, Sorokin L, Thornell LE, Wondimu Z, Assefa D, Patarroyo M, Virtanen I: Localization of laminin a4-chain in developing and adult human tissues. J Histochem Cytochem 2002, 50:1113-1130.

33. Tiger CF, Champliaud MF, Pedrosa-Domellöf F, Thornell LF, Ekblom P, Gullberg D: Presence of laminin a5 chain and lack of laminin a1 chain during human muscle development and in muscular dystrophies. J Biol Chem 1997, 272:28590-28595.

34. Gullberg D, Tiger CF, Velling T: Laminins during muscle development and in muscular dystrophies. Cell Mol Life Sci 1999, 30:442-460.

35. Patton BL, Connoll AM, Martin PT, Cunningham JM, Mehta S, Pestronk A Miner $\mathrm{JH}$, Sanes JR: Distribution of ten laminin chains in dystrophic and regenerating muscles. Neuromuscul Disord 1999, 9:423-433.

36. Schuler F, Sorokin LM: Expression of laminin isoforms in myogenic cells in vitro and in vivo. J Cell Sci 1995, 108:3795-3805.

37. Vachon PH, Loechel F, Xu H, Wewer UM, Engvall E: Merosin and laminin in myogenesis; specific requirements for merosin in myotubal stability and survival. J Cell Biol 1996, 134:1483-1497.
38. Miner $J H$, Cunningham J, Sanes JR: Roles for laminin in embryogenesis: exencephaly, syndactyly, and placentopathy in mice lacking the laminin a5 chain. J Cell Biol 1998, 143:1713-1723.

39. Edwards MM, Mammadova-Bach E, Alpy F, Klein A, Hicks WL, Roux M, Simon-Assmann P, Smith RS, Orend G, Wu J, Peachey NS, Naggert JK, Lefebvre O, Nishina PM: Mutations in Lama1 disrupt retinal vascular development and inner limiting membrane formation. J Biol Chem 2010, 285:7697-7711.

40. Hayashi YK, Engvall E, Arikawa-Hirasawa E, Goto K, Koga R, Nonaka I, Sugita $H$, Arahata $\mathrm{K}$ : Abnormal localization of laminin subunits in muscular dystrophies. J Neurol Sci 1993, 119:53-64.

41. Tomé FM, Evangelista T, Leclerc A, Sunada Y, Manole E, Estournet B, Barois A, Campbell KP, Fardeau M: Congenital muscular dystrophy with merosin deficiency. CR Acad Sci III 1994, 317:351-357.

42. Miyagoe Y, Hanaoka K, Nonaka I, Hayasaka M, Nabeshima Y, Arahata K, Nabeshima Y, Takeda S: Laminin a2 chain-null mutant mice by targeted disruption of the Lama2 gene: a new model of merosin (laminin 2)deficient congenital muscular dystrophy. FEBS Lett 1997, 415:33-39.

43. Kuang $W, X u H$, Vachon PH, Engvall E: Merosin-deficient congenital muscular dystrophy. Partial genetic correction in two mouse models. J Clin Invest 1998, 102:844-852.

44. Cohn RD, Herrmann R, Wewer UM, Voit T: Changes of laminin $\beta 2$ chain expression in congenital muscular dystrophy. Neuromuscul Disord 1997, 7:373-378

45. Sanes JR: The basement membrane/basal lamina of skeletal muscle. Biol Chem 2003, 278:12601-12604

46. Denzer AJ, Brandenberger R, Gesemann M, Chiquet M, Ruegg MA: Agrin binds to the nerve-muscle basal lamina via laminin. J Cell Biol 1997, 137:671-683

47. Feltri ML, Wrabetz L: Laminins and their receptors in Schwann cells and hereditary neuropathies. J Peripher Nerv Syst 2005, 10:128-143.

48. Gawlik Kl, Li JY, Petersen $\AA$, Durbeej M: Laminin a1 chain improves laminin a2 chain deficient neuropathy. Hum Mol Genet 2006, 15:2690-2700.

49. Engvall E, Earwicker D, Haaparanta T, Ruoslahti E, Sanes JR: Distribution and isolation of four laminin variants; tissue restricted distribution of heterotrimers assembled from five different subunits. Cell Regul 1990, 10:731-40.

50. Kuang $\mathrm{W}, \mathrm{Xu} \mathrm{H}$, Vachon $\mathrm{PH}$, Engvall E: Disruption of the lama2 gene in embryonic stem cells: laminin a2 is necessary for the sustenance of mature muscle cells. Exp Cell Res 1998, 241:117-125.

51. Desaki J, Matsuda S, Sakanaka M: Morphological changes of neuromuscular junctions in the dystrophic (dy) mouse: a scanning and transmission electron microscopic study. J Electron Microsc (Tokyo) 1995, 44:59-65.

52. Gubler MC: Inherited diseases of the glomerular basement membrane. Nat Clin Pract Nephrol 2008, 4:24-37.

53. Ibraghimov-Beskrovnaya O, Milatovich A, Ozcelik T, Yang B, Koepnick K, Francke U, Campbell KP: Human dystroglycan: skeletal muscle cDNA, genomic structure, origin of tissue specific isoforms and chromosomal localization. Hum Mol Genet 1993, 2:1651-1657.

54. Campbell KP, Kahl SD: Association of dystrophin and an integral membrane glycoprotein. Nature 1989, 338:259-262.

55. Ervasti JM, Campbell KP: A role for the dystrophin-glycoprotein complex as a transmembrane linker between laminin and actin. J Cell Biol 1993, 122:809-823.

56. Yoshida-Moriguchi T, Yu L, Stalnaker SH, Davis S, Kunz S, Madson M, Oldstone MB, Schachter H, Wells L, Campbell KP: O-mannosyl phosphorylation of a-dystroglycan is required for laminin binding. Science 2010, 327:88-92.

57. Tisi D, Talts JF, Timpl R, Hohenester E: Structure of the C-terminal laminin G-like domain pair of the laminin a2 chain harbouring binding sites for a-dystroglycan and heparin. EMBO J 2000, 19:1432-1440.

58. von der Mark H, Durr J, Sonnenberg A, von der Mark K, Deutzmann R, Goodman SL: Skeletal myoblasts utilize a novel $\beta 1$-series integrin and not a6 $\beta 1$ for binding to the E8 and T8 fragments of laminin. J Biol Chem 1991, 266:23593-23601.

59. Song WK, Wang W, Foster RF, Bielser DA, Kaufman SJ: H36- $\alpha$ 7 is a novel integrin a chain that is developmentally regulated during skeletal myogenesis. J Cell Biol 1992, 117:643-657. 
60. Vachon PH, Xu H, Liu L, Loechel F, Hayashi Y, Arahata K, Reed JC, Wewer UM, Engvall E: Integrins ( $a 7 \beta 1$ ) in muscle function and survival. Disrupted expression in merosin-deficient congenital muscular dystrophy. J Clin Invest 1997, 10:1870-1881.

61. Mayer U: Integrins: redundant or important players in skeletal muscle? J Biol Chem 2003, 278:14587-14590.

62. Conti FJ, Monkley SJ, Wood MR, Critchley DR, Muller U: Talin 1 and 2 are required for myoblast fusion, sarcomere assembly and the maintenance of myotendinous junction. Development 2009, 136:3597-3606.

63. Wang HV, Chang LW, Brixius K, Wickström SA, Montanez E, Thievessen I, Schwander M, Muller U, Bloch W, Mayer U, Fässler R: Integrin-linked kinase stabilizes myotendinous junctions and protects muscle from stressinduced damage. J Cell Biol 2008, 180:1037-1049.

64. Häger M, Bigotti MG, Meszaros R, Carmignac V, Holmberg J, Allamand V, Åkerlund M, Kalamajski S, Brancaccio A, Mayer U, Durbeej M: Cib2 binds integrin $\mathrm{a} B \mathrm{~B} \beta 1 \mathrm{D}$ and is reduced in laminin a2 chain-deficient muscular dystrophy. J Biol Chem 2008, 283:24760-247695.

65. Lisi MT, Cohn RD: Congenital muscular dystrophies: new aspects of an expanding group of disorders. Biochim Biophys Acta 2007, 1772:159-172.

66. Hayashi YK, Chou FL, Engvall E, Ogawa M, Matsuda C, Hirabayashi S, Yokochi K, Ziober BL, Kramer RH, Kaufman SJ, Ozawa E, Goto Y, Nonaka I, Tsukahara T, Wang JZ, Hoffman EP, Arahata K: Mutations in the integrin a7 gene cause congenital myopathy. Nat Genet 1998, 19:94-97.

67. Guo C, Willem M, Werner A, Raivich G, Emerson M, Neyses L, Mayer U: Absence of a7 integrin in dystrophin-deficient mice causes a myopathy similar to Duchenne muscular dystrophy. Hum Mol Genet 2006, 15:989-98.

68. Rooney JE, Welser JV, Dechert MA, Flintoff-Dye NL, Kaufman SJ, Burkin DJ: Severe muscular dystrophy in mice that lack dystrophin and a7 integrin. J Cell Sci 2006, 119:2185-2195.

69. Han R, Kanagawa M, Yoshida-Moriguchi T, Rader EP, Ng RA, Michele DE, Muirhead DE, Kunz S, Moore SA, lannaccone ST, Miyake K, McNeil PL, Mayer U, Oldstone MBA, Faulkner JA, Campbell KP: Basal lamina strengthens cell membrane integrity via the laminin $\mathrm{G}$ domainbinding motif of a-dystroglycan. Proc Natl Acad Sci USA 2009, 106:12573-12579.

70. Gawlik Kl, Åkerlund M, Carmignac V, Elamaa H, Durbeej M: Distinct roles for laminin globular domains in laminin a1 chain mediated rescue of murine laminin a2 chain deficiency. PLOS ONE 2010, 5:e11549.

71. Yang B, Jung D, Motto D, Meyer J, Koretzky G, Campbell KP: SH3 domainmediated interaction of dystroglycan and Grb2. J Biol Chem 1995, 270:11711-11714.

72. Zhou YW, Oak SA, Senogles SE, Jarrett HW: Laminin-a1 globular domains 3 and 4 induce heterotrimeric $\mathrm{G}$ protein binding to a-syntrophin's PDZ domain and alter intracellular $\mathrm{Ca}^{2+}$ in muscle. Am J Physiol Cell Physiol 2005, 288:C377-388

73. Zhou Y, Jiang D, Thomason DB, Jarrett HW: Laminin-induced activation of Rac1 and JNKp46 is initiated by Src family kinases and mimics the effects of skeletal muscle contraction. Biochemistry 2007, 46:14907-14916.

74. Langenbach KJ, Rando TA: Inhibition of dystroglycan binding to laminin disrupts the PI3K/AKT pathway and survival signaling in muscle cells. Muscle Nerve 2002, 26:644-653.

75. Xiong $Y$, Zhou $Y$, Jarrett HW: Dystrophin glycoprotein complex-associated $\mathrm{G} \beta Y$ subunits activate phosphatidylinositol-3-kinase/Akt signaling in skeletal muscle in a laminin-dependent manner. J Cell Physiol 2009, 219:402-414.

76. Laprise P, Poirier EM, Vezina A, Rivard N, Vachon PH: Merosin-integrin promotion of skeletal myofiber cell survival: Differentiation state-distinct involvement of p60Fyn tyrosine kinase and p38alpha stress-activated MAP kinase. J Cell Physiol 2002, 191:69-81.

77. Suzuki N, Yokoyama F, Nomizu M: Functional sites in the laminin alpha chains. Conn Tiss Res 2005, 46:142-152.

78. Allamand V, Guicheney P: Merosin-deficient muscular dystrophy, autosomal recessive (MDC1A, MIM\#156225, LAMA2 gene coding for a2 chain of laminin). Eur J Hum Genet 2002, 10:91-94.

79. Voit T, Tomé FS: The congenital muscular dystrophies. In Myology. Volume 2. Edited by: Angel A, Franzini-Armstrong C. New York: McGraw-Hill; 2004:1203-1238.

80. Geranmayeh F, Clement E, Feng LH, Sewry C, Pagan J, Mein R, Abbs S, Brueton L, Childs AM, Jungbluth H, De Goede CG, Lynch B, Lin JP, Chow G, Sousa C, O'Mahony O, Majumdar A, Straub V, Bushby K, Muntoni F: Genotype-phenotype correlation in a large population of muscular dystrophy patients with LAMA2 mutations. Neuromuscul Disord 2010, 4:241-250.

81. Mostacciuolo ML, Miorin M, Martinello F, Angelini C, Perini P, Trevisan CP: Genetic epidemiology of congenital muscular dystrophy in a sample from north-east Italy. Hum Genet 1996, 97:277-279.

82. Wang $\mathrm{CH}$, Bonnemann CG, Rutkowski A, Sejersen T, Bellini J, Battista $V$, Florence JM, Schara U, Schuler PM, Wahbi K, Aloysius A, Bash RO, Béroud C, Bertini E, Bushby K, Cohn RD, Connolly AM, Deconinck N, Desguerre I, Eagle M, Estournet-Mathiaud B, Ferreiro A, Fujak A, Goemans N, lannaccone ST, Jouinot P, Main M, Melacini P, Mueller-Felber W, Muntoni F, Nelson LL, Rahbek J, Quijano-Roy S, Sewry C, Storhaug K, Simonds A, Tseng B, Vajsar J, Vianello A, Zeller R: Consensus statement on standard care for congenital muscular dystrophies. J Child Neurol 2010, 25:1559-1581.

83. Guo LT, Zhang XU, Kuang $W, X u H$, Liu LA, Vilquin JT, Miyagoe-Suzuki $Y$, Takeda S, Ruegg MA, Wewer UM, Engvall E: Laminin a2 deficiency and muscular dystrophy; genotype-phenotype correlation in mutant mice. Neuromusc Disord 2003, 3:207-215.

84. Chun SJ, Rasband MN, Sidman RL, Habib AA, Vartanian T: Integrin-linked kinase is required for laminin-2-induced oligodendrocyte cell spreading and CNS myelination. J Cell Biol 2003, 163:397-408.

85. Xu H, Wu XR, Wewer UM, Engvall E: Murine muscular dystrophy caused by a mutation in the laminin a2 (Lama2) gene. Nat Genet 1994, 8:297-302

86. Sunada Y, Bernier SM, Utani A, Yamada Y, Campbell KP: Identification of a novel mutant transcript of laminin a2 chain gene responsible for muscular dystrophy and dysmyelination in dy2J mice. Hum Mol Genet 1995, 4:1055-1061.

87. Patton $B L$, Wang $B$, Tarumi $Y S$, Seburn KL, Burgess RW: A single point mutation in the LN domain of LAMA2 causes muscular dystrophy and peripheral amyelination. J Cell Sci 2008, 121:1593-1604.

88. Kuang W, Xu H, Vilquin JT, Engvall E: Activation of the lama2 gene in muscle regeneration: abortive regeneration in laminin a2-deficiency. Lab Invest 1999, 79:1601-1613.

89. Hayashi YK, Tezak Z, Momoi T, Nonaka I, Garcia CA, Hoffman EP, Arahata K: Massive muscle cell degeneration in the early stage of merosin-deficient congenital muscular dystrophy. Neuromuscul Disord 2001, 11:350-359.

90. Ervasti JM, Campbell KP: Membrane organization of the dystrophinglycoprotein complex. Cell 1993, 66:1121-1131.

91. Petrof BJ, Shrager JB, Stedman HH, Kelly AM, Sweeney HL: Dystrophin protects the sarcolemma from stresses developed during muscle contraction. Proc Natl Acad Sci USA 1993, 90:3710-3714.

92. Hall TE, Bryson-Richardson RJ, Berger S, Jacoby AS, Cole NJ, Hollway GE, Berger J, Currie PD: The zebrafish candyfloss mutant implies extracellular matrix adhesion failure in laminin a2-deficient congenital muscular dystrophy. Proc Natl Acad Sci USA 2007, 104:7093-7097.

93. Erb M, Meinen S, Barzaghi P, Sumanovski LT, Courdier-Fruh I, Ruegg MA, Meier T: Omigapil ameliorates the pathology of muscle dystrophy caused by laminin-a2 deficiency. J Pharmacol Exp Ther 2009, 331:787-795.

94. Sandri M: Autophagy in skeletal muscle. FEBS Lett 2010, 584:1411-1416.

95. Carmignac V, Quéré R, Durbeej M: Proteasome inhibition improves the muscle of laminin a2 chain-deficient mice. Hum Mol Genet 2011, 20:541-552.

96. Bonuccelli G, Sotiga F, Schubert W, Park DS, Frank PG, Woodman SE, Insabato L, Cammer M, Minetti C, Lisanti MP: Proteasome inhibitor (MG132) treatment of $\mathrm{mdx}$ mice rescues the expression and localization of dystrophin and dystrophin-associated proteins. Am J Path 2003, 163:1663-1675

97. Grumati P, Coletto L, Sabatelli P, Cescon M, Angelin A, Bertaggia E, Blaauw B, Urciuolo A, Tiepolo T, Merlini L, Maraldi NM, Bernardi P, Sandri M, Bonaldo P: Autophagy is defective in collagen VI muscular dystrophies, and its reactivation rescues myofiber degeneration. Nat Med 2010, 16:1313-1321.

98. Ringelmann B, Roder C, Hallmann R, Maley M, Davies M, Grounds M, Sorokin L: Expression of laminin a1, a2, a4, and a5 chains, fibronectin, and tenascin-C in skeletal muscle of dystrophic 129ReJ dy/dy mice. Exp Cell Res 1999, 246:165-182.

99. Talts JF, Sasaki T, Miosge N, Gohring W, Mann K, Mayne R, Timpl R: Structural and functional analyses of the recombinant $G$ domain of the laminin a4 chain and its proteolytic processing in tissues. J Biol Chem 2000, 275:35192-35199. 
100. Porter JD, Karathanasis P: Extraocular muscle in merosin-deficient muscular dystrophy: cation homeostasis is maintained but is not mechanistic in muscle sparing. Cell Tissue Res 1998, 292:495-501.

101. Nyström A, Holmblad J, Pedrosa-Domellöf F, Sasaki T, Durbeej M: Extraocular muscle is spared upon complete laminin a2 chain deficiency: comparative expression of laminin and integrin isoforms. Matrix Biol 2006, 25:382-385.

102. Hodges BS, Hayashi YK, Nonaka I, Wang A, Arahata K, Kaufman SJ: Altered expression of the $a 7 \beta 1$ integrin in human and murine muscular dystrophies. J Cell Sci 1997, 110:2873-2881.

103. Cohn RD, Mayer U, Saher G, Herrmann R, van der Flier A, Sonnenberg A, Sorokin $L$, Voit T: Secondary reduction of integrin a7B in laminin a2 deficient congenital muscular dystrophy supports an additional transmembrane link in skeletal muscle. J Neurol Sci 1999, 63:140-152.

104. Gawlik Kl, Mayer U, Blomberg K, Sonnenberg A, Ekblom P, Durbeej M: Laminin a1 chain mediated reduction of laminin a 2 chain deficient muscular dystrophy involves integrin $\alpha 7 \beta 1$ and dystroglycan. FEBS Lett 2006, 580:1759-1765.

105. Moll J, Barzaghi P, Lin S, Bezakova G, Lochmuller H, Engvall E, Muller U, Ruegg MA: An agrin minigene rescues dystrophic symptoms in a mouse model for congenital muscular dystrophy. Nature 2001, 413:302-307.

106. Jimenez-Mallebrera C, Torelli S, Feng L, Kim J, Godfrey C, Clement E, Mein R, Abbs S, Brown SC, Campbell KP, Kröger S, Talim B, Topaloglu H, Quinlivan R, Roper H, Childs AM, Kinali M, Sewry CA, Muntoni F: A comparative study of a-dystroglycan glycosylation in dystroglycanopathies suggests that the hypoglycosylation of alpha-dystroglycan does not consistently correlate with clinical severity. Brain Pathol 2009, 19:596-611.

107. Bentzinger CF, Barzaghi $P$, Lin S, Ruegg MA: Overexpression of mini-agrin in skeletal muscle increases muscle integrity and regenerative capacity in laminin-a2-deficient mice. FASEB J 2005, 19:934-942.

108. Gawlik K, Miyagoe-Suzuki Y, Ekblom P, Takeda S, Durbeej M: Laminin a1 chain reduces muscular dystrophy in laminin a2 chain deficient mice. Hum Mol Genet 2004, 13:1775-1784.

109. Xu R, Chandrasekharan K, Yoon JH, Camboni M, Martin PT: Overexpression of the cytotoxic T cell (CT) carbohydrate inhibits muscular dystrophy in the dy ${ }^{W}$ mouse model of congenital muscular dystrophy $1 \mathrm{~A}$. Am J Path 2007, 171:181-199.

110. Meinen S, Barzaghi $P$, Lin S, Lochmuller H, Ruegg MA: Linker molecules between laminins and dystroglycan ameliorate laminin- a2-deficient muscular dystrophy at all disease stages. J Cell Biol 2007, 176:979-993.

111. Gawlik Kl, Durbeej M: Transgenic overexpression of laminin a1 chain in laminin a2 chain-deficient mice rescues the disease throughout the lifespan. Muscle Nerve 2010, 42:30-37.

112. von der Mark H, Williams I, Wendler O, Sorokin L, von der Mark K, Pöschl E: Alternative splice variants of a7 $\beta 1$ integrin selectively recognize different laminin isoforms. J Biol Chem 2002, 277:6012-6016.

113. Qiao C, Li J, Zhu T, Draviam R, Watkins S, Ye X, Chen C, Li J, Xiao X: Amelioration of laminin-a2-deficient congenital muscular dystrophy by somatic gene transfer of miniagrin. Proc Natl Acad Sci USA 2005, 102:11999-12004.

114. Girgenrath M, Dominov JA, Kostek CA, Miller JB: Inhibition of apoptosis improves outcome in a model of congenital muscular dystrophy. J Clin Invest 2004, 114:1635-1639.

115. Dominov JA, Kravetz AJ, Ardelt M, Kostek CA, Beermann ML, Miller JB: Muscle-specific BCL2 expression ameliorates muscle disease in laminin a2-deficient, but not in dystrophin-deficient, mice. Hum Mol Genet 2005 14:1029-1040.

116. Girgenrath M, Beermann ML, Vishnudas VK, Homma S, Miller JB: Pathology is alleviated by doxycycline in a laminin-a2-null model of congenital muscular dystrophy. Ann Neurol 2009, 65:47-56.

117. Millay DP, Sargent MA, Osinska H, Baines CP, Barton ER, Vaugniaux G, Sweeney HL, Robbins J, Molkentin JD: Genetic and pharmacologic inhibition of mitochondrial-dependent necrosis attenuates muscular dystrophy. Nat Med 2008, 14:442-447.

118. Vilquin JT, Guerette B, Puymirat J, Yaffe D, Tome FMS, Fardeau M, Fiszman M, Schwartz K, Tremblay JP: Myoblast transplantations lead to the expression of the laminin a 2 chain in normal and dystrophic (dy/dy) mouse muscles. Gene Therapy 1999, 6:792-800.

119. Fukada S, Yamamoto Y, Segawa M, Sakamoto K, Nakajima M, Sato M, Morokawa D, Uezumi A, Miyagoe-Suzuki Y, Takeda S, Tsujikawa K, Yamamoto H: CD90-postive cells, an additional cell population, produce laminin a2 chain upon transplantation in $d y^{3 k} / d y^{3 k}$ mice. Exp Cell Res 2007, 314:193-203.

120. Hagiwara H, Ohsawa Y, Asakura S, Murakami T, Teshima T, Sunada Y: Bone marrow transplantation improves outcome in a mouse model of congenital muscular dystrophy. FEBS Lett 2006, 580:4463-4468.

121. Pillers DA, Kempton JB, Duncan NM, Pang J, Dwinnel SJ, Trune DR: Hearing loss in the laminin-deficient dy mouse model of congenital muscular dystrophy. Mol Genet Metab 2002, 76:217-224.

122. Wagner WJ, Chang AC, Owens J, Hong MJ, Brooks A, Coligan JE: Aberrant development of thymocytes in mice lacking laminin-2. Dev Immunol 2000, 7:179-193.

123. Nakagawa M, Miyagoe-Suzuki Y, Ikezoe K, Miyata Y, Nonaka I, Harii K, Takeda S: Schwann cell myelination occurred without basal lamina formation in laminin a2 chain-null mutant $\left(\mathrm{dy}^{3 \mathrm{~K}} / \mathrm{dy}^{3 \mathrm{~K}}\right)$ mice. Glia 2001, 35:101-110.

124. Häger M, Gawlik K, Nyström A, Sasaki T, Durbeej M: Laminin a1 chain corrects male infertility caused by absence of laminin a2 chain. Am J Path 2005, 167:823-833.

125. Yuasa K, Fukumoto S, Kamasaki Y, Yamada A, Fukumoto E, Kanaoka K, Saito K, Harada H, Arikawa-Hirasawa E, Miyagoe-Suzuki Y, Takeda S, Okamoto K, Kato Y, Fujiwara T: Laminin a2 is essential for odontoblast differentiation regulating dentin sialoprotein expression. $J$ Biol Chem 2004, 279:10286-10292.

126. Besse S, Allamand V, Vilquin JT, Li Z, Poirier C, Vignier N, Hori H, Guenet JL, Guicheney P: Spontaneous muscular dystrophy caused by a retrotransposal insertion in the mouse laminin a 2 chain gene. Neuromuscul Disord 2003, 13:216-222.

doi:10.1186/2044-5040-1-9

Cite this article as: Gawlik and Durbeej: Skeletal muscle laminin and MDC1A: pathogenesis and treatment strategies. Skeletal Muscle 2011 1:9.

\section{Submit your next manuscript to BioMed Central and take full advantage of:}

- Convenient online submission

- Thorough peer review

- No space constraints or color figure charges

- Immediate publication on acceptance

- Inclusion in PubMed, CAS, Scopus and Google Scholar

- Research which is freely available for redistribution 